\title{
RAMIFICATIONS OF QUANTUM PHYSICS FOR EDUCATION
}

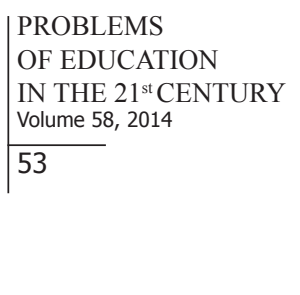

\author{
Selma Dundar-Coecke \\ University of Oxford, Oxford, United Kingdom \\ E-mail: selma.dundar@cs.ox.ac.uk, s.selma.dundar@gmail.com
}

\begin{abstract}
The purpose of this study is to understand whether the developments in physics, particularly in quantum theory, can have an impact on education. Throughout the research a mixed method strategy was used. Previously, we obtained qualitative data from a focus group which consisted of six physicists working at $C E R N$. From this qualitative data a research question emerged, on which we report here. The data were obtained by survey and subjected to chi-square analysis, as well as frequency distributions. Based on the obtained results, the possible impact of developments in quantum theory on education are discussed, hereby aiming to contribute to the philosophy of science in an educational framework. Consequently, this discussion produces three rich topics for future investigation.
\end{abstract}

Key words: educational sciences, philosophical impacts, quantum theory.

\section{Introduction}

After physics branched out of philosophy, it has pioneered other disciplines. In fact, physics is the present-day equivalent of what used to be called natural philosophy, from which most of our modern sciences arose (Gottlieb et al, 2013). The relationship between philosophy and physics can easily be seen from a Kuhnian perspective on how science develops. Kuhn (1962) explicates progress in science not as a linear process of theoretical formulation and experimental verification or refutation of scientific theories, but in terms of revolutions and changes of paradigm. Paradigms include ways of looking at the world, practices of instrumentation, traditions of research, and shared values and beliefs about which questions fall within science's domain. Currently, studies in physics also closely underline the fundamental philosophical questions, such as how matter and energy interact.

Significant developments in physics since the beginning of the twentieth century, particularly the discovery of Planck's constant, have accompanied a new understanding in science. With Heisenberg's (1958) words, "A first and very interesting step toward a real understanding of quantum theory was taken by Bohr, Kramers and Slater in 1924." Later, the Solvay Conferences held in 1911, 1930, and 1935 crystallized some of the answers for conflicting ontological questions based on quantum physics. One of the most famous and ironic was "Does the Moon exist when we're not looking?" Both epistemologically and ontologically the Copenhagen Interpretation clashed with the EPR (Einstein, Podolsky, and Rosen) experiment and classical (Newtonian) belief regarding the essential separateness of subject and object. Bohr decelerated the antagonist nature of observation; he (1937) described his viewpoint as complementarity. Heisenberg (1958) explained his uncertainty principle; quantum has the capacity to act as a particle with a position as well as a wave with momentum. Momentum and position cannot be known simultaneously. This means that if we know the position, the momentum will become uncertain. This is why the Copenhagen Interpretation focused mainly on measurement and the limitation of its efficacy in the quantum realm (Jeager, 2009).

The step from classical to quantum mechanics is obviously revolutionary in Kuhn's sense of the term. Now physicists clearly say that quantum theory forces us to think beyond the ordinary. In other words, quantum physics has revolutionized our understanding of reality. This also 
PROBLEMS

OF EDUCATION

IN THE $21^{\text {st }}$ CENTURY Volume 58,2014

54

ends the clockwork universe view of determinism. The foundation of this revolution is based on different interpretations such as Copenhagen Interpretation, (Bohr, 1937, 1961; Heisenberg, 1958), the Orthodoxy Explanation (Bohm, 1989; Peat, 1990), and the Basic Interpretation (Jammer, 1989). It is not easy to give a brief overview for the foundation of this revolution. We also should consider literature about Schrödinger's wave mechanics (Healey, 1989; Schreiber, 1994; Parker, 2006), the problem of properties (Penrose, 1989; Deutsch, 1997) which includes the EPR Paradox (Einstein et al, 1935; Lindley, 2007), the Double Slit Experiment (Mittelstaedt, 1987), Hidden Variables (Bohm, 1989), Measurement (Heisenberg, 1958; Maudlin, 1995; Pagels, 2003), Quantum Entanglement (Bell, 1966, 1987, 1997; Bokulich et al, 2010; Bub, 2010) and recent developments in physics. Additionally, the literature has had ramifications across a variety of disciplines. Penrose (1999), Hameroff (quantumconsciousness.com), and growing number of physicists, neuroscientists, and philosophers argue that consciousness itself may be a quantum mechanical phenomenon.

Philosophy of mind, as a branch of philosophy, examines what cognition is and how it works from a different perspective, with the help of other sciences such as psychology and education. For example, Heideger's essay Modern Science, Metaphysics, and Mathematics also represent a significant contribution to interdisciplinary connections between theories in the physical and the human sciences (cited by Desilet, 1999).

\section{Problem of Research}

Education is one of the most interdisciplinary fields. The field's interdisciplinarity derives from several of its core characteristics, including from its aim of developing individuals' potential to learn. As human beings, we have to learn. In Vygotsky's (1986) words learning always precedes development; acquisition of new knowledge is dependent on previous learning. Secondly, education helps us to improve our creativity by using clues, and innovatively building on our knowledge. At this point the paths of philosophy and education cross, because using clues to find out different possibilities about what we know is also the main problem of epistemology and ontology, which also demand that we continuously examine our knowledge of reality. It also supports the third goal of education, which is to help one's self-actualization. With the help of this perspective, preliminary research (Dundar, 2013) results showed that despite dissimilarities between physics and educational sciences, the developments in physics have brought new points of view to the educational sciences through the new understanding of the world it has made possible. At this point, examining physicists' experiences in favour of education is crucial.

Considering the preliminary results, the research question of this study is as follows: "Which fields in educational sciences might be influenced by recent developments in physics?" In line with this question, this research hypothesizes that: (1) Developments in physics reveal the need for an enhanced language and way of thinking. (2) The necessity of an enhanced language and way of thinking resulting from those recent developments in physics has impacted all fields of educational sciences.

\section{Methodology of Research}

\section{General Background of Research}

This research represents the quantitative part of a mixed-method study. The study used one of the most appropriate mixed method (Teddlie et al, 2009) designs in educational research; an explanatory sequential design (Creswell, 2005), consisting of two distinct phases. This design began by collecting and analysing qualitative data to explore a phenomenon (Strauss, 1987; Patton, 1990; Creswell, 2005) and investigate the suitability of research questions. From 
the initial exploratory results (Smith et al, 2006), the research arrived at the second phase, in which quantitative data were collected and analyzed to generalize the initial findings. Because of the complexity of the research topic, the data was obtained through a questionnaire derived from the qualitative part of the research and analyzed with the chi-square test technique in the study. This kind of integration between qualitative and quantitative methods provided the most comprehensive answers for examining the research question.

\section{Sample of Research} follows.

The sampling frame consisted of $108 \mathrm{CERN}$ physicists distributed by nationalities as

Table 1. Distribution of the participants' nationalities.

\begin{tabular}{llllllllll}
\hline Argentina & 1 & Brazil & 7 & Denmark & 1 & Italy & 22 & Sweden & 1 \\
\hline Armenia & 3 & UK & 7 & France & 6 & Palestine & 1 & Switzerland & 9 \\
\hline Austria & 4 & Bulgaria & 1 & Germany & 7 & Poland & 3 & Turkey & 8 \\
\hline Azerbaijan & 2 & Canada & 4 & Greece & 1 & San Marino & 1 & Ukraine & 1 \\
\hline Belgium & 5 & China & 2 & Hungary & 2 & Spain & 6 & USA & 3 \\
\hline
\end{tabular}

108 participants represented 25 different countries as can be seen in Table 1. According to participants' experiment groups the distribution is as follows.

Table 2. Experiment groups of the participants.

\begin{tabular}{lll}
\hline Experiment groups & $\mathbf{N}$ & $\%$ \\
\hline ALICE & 12 & 11.1 \\
ATLAS & 20 & 18.6 \\
ALPHA & 6 & 5.5 \\
CAST & 5 & 4.6 \\
CMS & 15 & 13.9 \\
LHCb & 9 & 8.3 \\
TOTEM & 4 & 3.7 \\
Theoretical physics (antimatter, astro-particle physics, string theory, quantum field theory, phe- & & \\
nomenology, probability etc.) & 37 & 34.3 \\
Total & 108 & 100 \\
\hline
\end{tabular}

Table 2 shows that $34.3 \%$ of the participants represented theoretical division, and $65.7 \%$ of the participants represented 7 different experiment groups.

The next question inquired into the experience levels of the participants. Table 3 shows their working years in the field. 
Selma Dundar-Coecke. Ramifications of Quantum Physics for Education

PROBLEMS

OF EDUCATION

IN THE $21^{\text {st }}$ CENTURY

Volume 58,2014

Table 3. Working years of the participants.

\begin{tabular}{lll}
\hline Years & N & $\%$ \\
\hline $1-5$ years & 33 & 30.8 \\
$6-10$ years & 27 & 25.2 \\
$11-15$ years & 7 & 6.5 \\
$16-20$ years & 14 & 13.1 \\
$21-25$ years & 4 & 3.7 \\
26 years and over & 22 & 20.7 \\
Total & 107 & 100 \\
\hline
\end{tabular}

The survey asked the respondents to identify how many years, in total, they had been in practice to ascertain tenure in the field. All but one participant responded, and the distribution of the participants' experience in the field shows variety.

\section{Instrument and Procedures}

The questionnaire, entitled Philosophical Impacts of New Physics on Educational Sciences (PINPE), established by researcher throughout the results of the qualitative part of this study. The first version of PINPE had nine questions. The first four questions examined physicists' demographic attributes including a question that inquired about gender. After receiving some criticism via emails from some of the respondents, the question about gender was removed from the questionnaire. Remaining five questions aimed to investigate hypotheses of the research. These five multiple-choice questions focused on context and content. In total, the final survey consisted of eight questions.

Data in the quantitative phase were generated through the PINPE, sent to 796 physicists via emails from different departments and experiment groups in CERN. Permission to use the PINPE was requested from experiment group coordinators and managers. The survey was administered in the Spring of 2013 within a 3-month period. The survey was expected to take 10 minutes to complete. The survey results were collected by Surveymonkey, and the researcher was given a separate key to access collected data from each survey period. 108 complete questionnaires were obtained at the end of third month, for an average response rate of $13.5 \%$.

\section{Data Analysis}

Obtained data were transferred to SPSS programme and analyzed with the chi-square test technique, as well as with frequency distributions. Chi-square analysis was evaluated with a $95 \%$ confidence level to enhance reliability. The chi-square test of statistical significance let us know the degree of confidence in accepting or rejecting the null hypothesis, which states that whether there is significant difference between the expected (research hypotheses) and observed result.

\section{Results of Research}

Findings herein have provided an overview to understand which fields in educational sciences might be influenced by recent developments in physics from the perspectives of scientists working at CERN. Each question was organized independently to provide an overview of its frequency distributions and chi-square results. 
Question 1

The first question asked physicists if "New physics forces us to change our view of physical reality." Respondents answered the question on a 4-point Likert-type scale. Distributions of responses can be seen in the Table 4.

Table 4. Frequency distribution of responses.

\begin{tabular}{lll}
\hline & N & $\%$ \\
\hline Definitely No & 0 & 0.0 \\
No & 12 & 11.2 \\
Yes & 46 & 43.0 \\
Definitely Yes & 49 & 45.8 \\
Total & 107 & 100 \\
\hline
\end{tabular}

The distribution of the data shows that $11.2 \%$ of respondents disagreed, $43 \%$ of participants agreed, and $45.8 \%$ of participants definitely agreed with this statement. In total $88.8 \%$ of participants expressed a positive response to this question. Chi-square analysis results for theory and experiment group differences are as follows.

Table 5. Chi-square results according to divisional differences.

\begin{tabular}{|c|c|c|c|c|c|c|}
\hline & & & Experimentalists & Theorists & Total & \\
\hline \multirow{6}{*}{$\begin{array}{l}\text { New physics forces us } \\
\text { to change our view of } \\
\text { physical reality. }\end{array}$} & \multirow{2}{*}{ No } & $\mathrm{N}$ & 9 & 3 & 12 & \multirow{7}{*}{$\begin{array}{l}\text { Chi-square: } 1.634 \\
\text { df: } 2 \\
\text { p: } 0.442\end{array}$} \\
\hline & & $\%$ & 13.4 & 8.1 & 11.5 & \\
\hline & \multirow{2}{*}{ Yes } & $\mathrm{N}$ & 30 & 14 & 44 & \\
\hline & & $\%$ & 44.8 & 37.8 & 42.3 & \\
\hline & \multirow{2}{*}{ Definitely Yes } & $\mathrm{N}$ & 28 & 20 & 48 & \\
\hline & & $\%$ & 41.8 & 54.1 & 46.2 & \\
\hline Total & & $\mathrm{N}$ & 67 & 37 & 104 & \\
\hline
\end{tabular}

According to chi-square test results, there is no significant difference for this question between the answers obtained from the working groups (Chi-square: 1.634, df: 2, p>0.05). Chisquare analysis results for the participants' experience are as follows.

Table 6. Chi-square results according to participants' experience.

\begin{tabular}{|c|c|c|c|c|c|c|c|}
\hline & & & $\begin{array}{l}1-5 \\
\text { years }\end{array}$ & $\begin{array}{l}6-10 \\
\text { years }\end{array}$ & $\begin{array}{l}11 \text { and } \\
\text { over }\end{array}$ & Total & \\
\hline \multirow{6}{*}{$\begin{array}{l}\text { New physics forces us to } \\
\text { change our view of physi- } \\
\text { cal reality. }\end{array}$} & \multirow{2}{*}{ No } & $\mathrm{N}$ & 6 & 1 & 5 & 12 & \multirow{7}{*}{$\begin{array}{l}\text { Chi-square: } 6.256 \\
\text { df: } 4 \\
\text { p: } 0.181\end{array}$} \\
\hline & & $\%$ & 17.1 & 4.2 & 10.6 & 11.3 & \\
\hline & \multirow{4}{*}{ Definitely Yes } & $\mathrm{N}$ & 16 & 14 & 16 & 46 & \\
\hline & & $\%$ & 45.7 & 58.3 & 34.0 & 43.4 & \\
\hline & & $\mathrm{N}$ & 13 & 9 & 26 & 48 & \\
\hline & & $\%$ & 37.1 & 37.5 & 55.3 & 45.3 & \\
\hline \multicolumn{2}{|l|}{ Total } & $\mathrm{N}$ & 35 & 24 & 47 & 106 & \\
\hline
\end{tabular}


Selma Dundar-Coecke. Ramifications of Quantum Physics for Education

PROBLEMS

OF EDUCATION

IN THE $21^{\text {st }}$ CENTURY

Volume 58,2014

Considering experience of the participants' responses did not differ for this question (Chi-square: 6.256, df: 4, $\mathrm{p}>0.05$ ).

Question 2

In relation to the previous question, physicists were asked if "Developments after quantum theory are revealing the need for new ways of thinking." Respondents answered the question on a 4-point Likert-type scale. Distributions of responses are as follows.

Table 7. Frequency distribution of responses.

\begin{tabular}{lll}
\hline & N & $\%$ \\
\hline Definitely No & 0 & 0.0 \\
No & 12 & 11.1 \\
Yes & 45 & 41.7 \\
Definitely Yes & 51 & 47.2 \\
Total & 108 & 100 \\
\hline
\end{tabular}

The distribution of data shows that $11.1 \%$ of respondents disagreed with this expression. $41.7 \%$ of participants agreed, $47.2 \%$ of participants definitely agreed with this statement. In total $88.9 \%$ of participants expressed a positive response to this question. Chi-square analysis results for theory and experiment group differences are as follows.

Table 8. Chi-square results according to divisional differences.

\begin{tabular}{llllllll}
\hline & & & Experimentalists & Theorists & Total & \\
\hline & & $N$ & 7 & 5 & 12 & \\
Developments after quan- & & $\%$ & 10.3 & 13.5 & 11.4 & \\
tum theory are revealing & Yes & $\mathrm{N}$ & 28 & 15 & 43 & Chi-square: 0.253 \\
the need for new ways of & & $\%$ & 41.2 & 40.5 & 41.0 & $\mathrm{df:} 2$ \\
thinking. & $\mathrm{N}$ & 33 & 17 & 50 & $\mathrm{p}: 0.881$ \\
& Definitely Yes & $\%$ & 48.5 & 45.9 & 47.6 & \\
& & $\mathrm{~N}$ & 68 & 37 & 105 & \\
\hline
\end{tabular}

Chi-square test results show that there is no significant difference for this question between the answers obtained from the working groups (Chi-square: $0.253, \mathrm{df}: 2, \mathrm{p}>0.05$ ). Chisquare analysis results for experience levels of the participants' are as follows.

Table 9. Chi-square results according to participants' experience.

\begin{tabular}{|c|c|c|c|c|c|c|c|}
\hline & & & $\begin{array}{l}1-5 \\
\text { years }\end{array}$ & $\begin{array}{l}6-10 \\
\text { years }\end{array}$ & $\begin{array}{l}11 \text { and } \\
\text { over }\end{array}$ & Total & \\
\hline \multirow{6}{*}{$\begin{array}{l}\text { Developments after quan- } \\
\text { tum theory are revealing } \\
\text { the need for new ways of } \\
\text { thinking. }\end{array}$} & \multirow{2}{*}{ No } & $\mathrm{N}$ & 4 & 2 & 6 & 12 & \multirow{7}{*}{$\begin{array}{l}\text { Chi-square: } 4.001 \\
\text { df: } 4 \\
\text { p: } 0.406\end{array}$} \\
\hline & & $\%$ & 11.1 & 8.3 & 12.8 & 11.2 & \\
\hline & \multirow{2}{*}{ Yes } & $\mathrm{N}$ & 14 & 14 & 16 & 44 & \\
\hline & & $\%$ & 38.9 & 58.3 & 34.0 & 41.1 & \\
\hline & \multirow{2}{*}{ Definitely Yes } & $\mathrm{N}$ & 18 & 8 & 25 & 51 & \\
\hline & & $\%$ & 50.0 & 33.3 & 53.2 & 47.7 & \\
\hline Total & & $\mathrm{N}$ & 36 & 24 & 47 & 107 & \\
\hline
\end{tabular}


Considering the experience of the participants' responses did not differ for this question

square: 4.001, df: 4, $\mathrm{p}>0.05$ ).

Question 3

The third question asked physicists "Which of the following sentences is suitable to express the abstract world of quantum mechanics?" Respondents chose one of two provided answers. Distributions of responses are as follows.

Table 10. Frequency distribution of responses.

\begin{tabular}{lll}
\hline & $\mathbf{N}$ & $\%$ \\
\hline A completely new language is required. & 37 & 34.9 \\
Existing languages should be enhanced with new words, symbols or diagrams. & 69 & 65.1 \\
Total & 106 & 100 \\
\hline
\end{tabular}

According to the distribution of the data, 34.9\% of respondents feel the necessity of a completely new language, while $65.1 \%$ of participants have been feeling the necessity of enhancing the existing vocabulary with new words, symbols or diagrams. Chi-square analysis results for theory and experiment group differences are as follows.

Table 11. Chi-square results according to divisional differences.

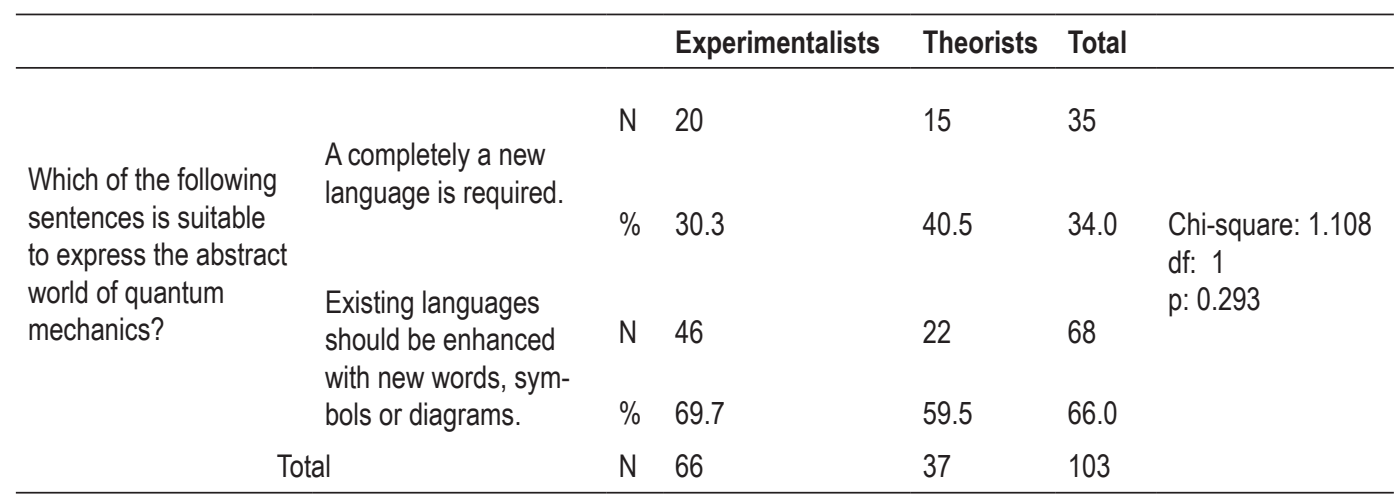

As can bee seen in Table 11, there is no significant difference for this question between the answers obtained from working groups (Chi-square: 1.108, df: $1, p>0.05$ ). Chi-square analysis results for experience of the participants are as follows.

Table 12. Chi-square results according to participants' experience.

\begin{tabular}{|c|c|c|c|c|c|c|c|}
\hline & & & $\begin{array}{l}1-5 \\
\text { years }\end{array}$ & $\begin{array}{l}6-10 \\
\text { years }\end{array}$ & $\begin{array}{l}11 \text { and } \\
\text { over }\end{array}$ & Total & \\
\hline \multirow{4}{*}{$\begin{array}{l}\text { Which of the fol- } \\
\text { lowing sentences is } \\
\text { suitable to express } \\
\text { the abstract world of } \\
\text { quantum mechanics? }\end{array}$} & Completely a new language is & $\mathrm{N}$ & 9 & 9 & 19 & 37 & \multirow{4}{*}{$\begin{array}{l}\text { Chi-square: } 1.753 \\
\text { df: } 2 \\
\text { p: } 0.416\end{array}$} \\
\hline & required. & $\%$ & 26.5 & 37.5 & 40.4 & 35.2 & \\
\hline & $\begin{array}{l}\text { Existing languages should be } \\
\text { enhanced with new words, }\end{array}$ & $\mathrm{N}$ & 25 & 15 & 28 & 68 & \\
\hline & symbols or diagrams. & $\%$ & 73.5 & 62.5 & 59.6 & 64.8 & \\
\hline \multicolumn{2}{|c|}{ Total } & $\mathrm{N}$ & 34 & 24 & 47 & 105 & \\
\hline
\end{tabular}


Selma Dundar-Coecke. Ramifications of Quantum Physics for Education

PROBLEMS

OF EDUCATION

IN THE $21^{\text {st }}$ CENTURY

Volume 58,2014

Considering the experience of the participants' responses did not differ for this question (Chi-square: 1.753, df: 2, $\mathrm{p}>0.05$ ).

Question 4

In order to reveal physicists' opinions about which field(s) in educational sciences might be influenced by recent developments in physics, the fourth question asked physicists, "Which of the following fields in educational science might have been influenced by developments in physics?" Respondents chose answers to a multiple-choice question. Distributions of responses are as follows.

Table 13. Frequency distribution of responses.

\begin{tabular}{lllll}
\hline & \multicolumn{3}{c}{ Yes } & \multicolumn{3}{c}{ Total } \\
\cline { 2 - 5 } & $\mathbf{N}$ & $\%$ & $\mathrm{~N}$ & $\%$ \\
\hline Targets of education (why we teach?) & 41 & 38.0 & 108 & 100 \\
Curriculum (what we teach?) & 87 & 80.6 & 108 & 100 \\
Teaching-learning techniques (how and where we teach?) & 48 & 44.4 & 108 & 100 \\
Measurement and Evaluation (what is learned?) & 58 & 53.7 & 108 & 100 \\
Psychology and counselling (helping one's self-realization) & 20 & 18.5 & 108 & 100 \\
\hline
\end{tabular}

Frequency distribution shows that $80.6 \%$ of respondents think that the field curriculum has been influenced by recent developments in physics. $53.7 \%$ of participants pointed to the field of measurement and evaluation; $44.4 \%$ of participants referred to teaching-learning techniques; $38 \%$ of the participants pointed to targets of education; and $18.5 \%$ of the participants answered the field psychology and counselling for this question. Chi-square analysis results for theory and experiment group differentials are as follows. 
Table 14. Chi-square results according to divisional differences.

\begin{tabular}{|c|c|c|c|c|c|c|}
\hline & & & Experimentalists & Theorists & Total & \\
\hline \multirow{4}{*}{$\begin{array}{l}\text { Targets of education } \\
\text { (why we teach?) }\end{array}$} & \multirow{2}{*}{ Yes } & $\mathrm{N}$ & 27 & 13 & 40 & \multirow{4}{*}{$\begin{array}{l}\text { Chi-square: } 1.212 \\
\text { df: } 1 \\
\text { p: } 0.645\end{array}$} \\
\hline & & $\%$ & 39.7 & 35.1 & 38.1 & \\
\hline & \multirow{2}{*}{ No } & $\mathrm{N}$ & 41 & 24 & 65 & \\
\hline & & $\%$ & 60.3 & 64.9 & 61.9 & \\
\hline Total & & $\mathrm{N}$ & 68 & 37 & 105 & \\
\hline \multirow{4}{*}{$\begin{array}{l}\text { Curriculum } \\
\text { (what we teach?) }\end{array}$} & \multirow{2}{*}{ Yes } & $\mathrm{N}$ & 50 & 34 & 84 & \multirow{4}{*}{$\begin{array}{l}\text { Chi-square: } 5.050 \\
\text { df: } 1 \\
\text { p: } 0.025\end{array}$} \\
\hline & & $\%$ & 73.5 & 91.9 & 80.0 & \\
\hline & \multirow{2}{*}{ No } & $\mathrm{N}$ & 18 & 3 & 21 & \\
\hline & & $\%$ & 26.5 & 8.1 & 20.0 & \\
\hline Total & & $\mathrm{N}$ & 68 & 37 & 105 & \\
\hline \multirow{4}{*}{$\begin{array}{l}\text { Teaching-learning } \\
\text { techniques } \\
\text { (how and where we } \\
\text { teach?) }\end{array}$} & \multirow{2}{*}{ Yes } & $\mathrm{N}$ & 33 & 14 & 47 & \multirow{4}{*}{$\begin{array}{l}\text { Chi-square: } 1.108 \\
\text { df: } 1 \\
\text { p: } 0.293\end{array}$} \\
\hline & & $\%$ & 48.5 & 37.8 & 44.8 & \\
\hline & \multirow{2}{*}{ No } & $\mathrm{N}$ & 35 & 23 & 58 & \\
\hline & & $\%$ & 51.5 & 62.2 & 55.2 & \\
\hline Total & & $\mathrm{N}$ & 68 & 37 & 105 & \\
\hline \multirow{4}{*}{$\begin{array}{l}\text { Measurement and } \\
\text { Evaluation } \\
\text { (what is learned?) }\end{array}$} & \multirow{2}{*}{ Yes } & $\mathrm{N}$ & 41 & 15 & 56 & \multirow{4}{*}{$\begin{array}{l}\text { Chi-square: } 3.757 \\
\text { df: } 1 \\
\text { p: } 0.053\end{array}$} \\
\hline & & $\%$ & 60.3 & 40.5 & 53.3 & \\
\hline & \multirow{2}{*}{ No } & $\mathrm{N}$ & 27 & 22 & 49 & \\
\hline & & $\%$ & 39.7 & 59.5 & 46.7 & \\
\hline Total & \multirow{3}{*}{ Yes } & $\mathrm{N}$ & 68 & 37 & 105 & \multirow{7}{*}{$\begin{array}{l}\text { Chi-square: } 1.135 \\
\text { df: } 1 \\
\text { p: } 0.287\end{array}$} \\
\hline \multirow{4}{*}{$\begin{array}{l}\text { Psychology and coun- } \\
\text { selling } \\
\text { (helping one's self- } \\
\text { realization) }\end{array}$} & & $\mathrm{N}$ & 15 & 5 & 20 & \\
\hline & & $\%$ & 22.1 & 13.5 & 19.0 & \\
\hline & \multirow{2}{*}{ No } & $\mathrm{N}$ & 53 & 32 & 85 & \\
\hline & & $\%$ & 77.9 & 86.5 & 81.0 & \\
\hline \multirow{2}{*}{ Total } & & $\mathrm{N}$ & 68 & 37 & 105 & \\
\hline & & $\%$ & 100 & 100 & 100 & \\
\hline
\end{tabular}

Table 14 shows that there is a significant difference for this question between the answers obtained from working groups (Chi-square: 5.050, df: 1, p $<0.05$ ). $73.5 \%$ of experimentalists, and $91.9 \%$ of theorists think that the field curriculum has been influenced by recent developments in physics. Accordingly, the participation rate of the experimentalists is significantly lower than theorists for this question. Chi-square analysis results for experiences of the participants' are as follows. 
Selma Dundar-Coecke. Ramifications of Quantum Physics for Education

OF EDUCATIC

PROBLEMS

IN THE $21^{\text {st }}$ CENTURY

Volume 58,2014

Table 15. Chi-square results according to participants' experience.

\begin{tabular}{|c|c|c|c|c|c|c|c|}
\hline & & & $\begin{array}{l}1-5 \\
\text { years }\end{array}$ & $\begin{array}{l}6-10 \\
\text { years }\end{array}$ & $\begin{array}{l}11 \text { and } \\
\text { over }\end{array}$ & Total & \\
\hline \multirow{4}{*}{$\begin{array}{l}\text { Targets of education } \\
\text { (why we teach?) }\end{array}$} & \multirow{2}{*}{ Yes } & $\mathrm{N}$ & 10 & 7 & 24 & 41 & \multirow{4}{*}{$\begin{array}{l}\text { Chi-square: } 5.773 \\
\text { df: } 2 \\
\text { p: } 0.056\end{array}$} \\
\hline & & $\%$ & 27.8 & 29.2 & 51.1 & 38.3 & \\
\hline & \multirow{2}{*}{ No } & $\mathrm{N}$ & 26 & 17 & 23 & 66 & \\
\hline & & $\%$ & 72.2 & 70.8 & 48.9 & 61.7 & \\
\hline \multirow[t]{2}{*}{ Total } & \multirow{3}{*}{ Yes } & $\mathrm{N}$ & 36 & 24 & 47 & 107 & \\
\hline & & $\mathrm{N}$ & 27 & 18 & 41 & 86 & \multirow{4}{*}{$\begin{array}{l}\text { Chi-square: } 2.501 \\
\text { df: } 2 \\
\text { p: } 0.286\end{array}$} \\
\hline \multirow{3}{*}{$\begin{array}{l}\text { Curriculum } \\
\text { (what we teach?) }\end{array}$} & & $\%$ & 75.0 & 75.0 & 87.2 & 80.4 & \\
\hline & \multirow{2}{*}{ No } & $\mathrm{N}$ & 9 & 6 & 6 & 21 & \\
\hline & & $\%$ & 25.0 & 25.0 & 12.8 & 19.6 & \\
\hline \multirow[t]{2}{*}{ Total } & & $\mathrm{N}$ & 36 & 24 & 47 & 107 & \\
\hline & & $\mathrm{N}$ & 18 & 9 & 21 & 48 & \multirow{4}{*}{$\begin{array}{l}\text { Chi-square: } 0.911 \\
\text { df: } 2 \\
\text { p: } 0.634\end{array}$} \\
\hline \multirow{3}{*}{$\begin{array}{l}\text { Teaching-learning tech- } \\
\text { niques } \\
\text { (how and where we teach?) }\end{array}$} & Yes & $\%$ & 50.0 & 37.5 & 44.7 & 44.9 & \\
\hline & \multirow{2}{*}{ No } & $\mathrm{N}$ & 18 & 15 & 26 & 59 & \\
\hline & & $\%$ & 50.0 & 62.5 & 55.3 & 55.1 & \\
\hline Total & & $\mathrm{N}$ & 36 & 24 & 47 & 107 & \\
\hline \multirow{4}{*}{$\begin{array}{l}\text { Measurement and Evalu- } \\
\text { ation } \\
\text { (what is learned?) }\end{array}$} & \multirow{2}{*}{ Yes } & $N$ & 22 & 9 & 26 & 57 & \multirow{4}{*}{$\begin{array}{l}\text { Chi-square: } 3.366 \\
\text { df: } 2 \\
\text { p: } 0.186\end{array}$} \\
\hline & & $\%$ & 61.1 & 37.5 & 55.3 & 53.3 & \\
\hline & \multirow{2}{*}{ No } & $\mathrm{N}$ & 14 & 15 & 21 & 50 & \\
\hline & & $\%$ & 38.9 & 62.5 & 44.7 & 46.7 & \\
\hline Total & & $\%$ & 100 & 100 & 100 & 100 & \\
\hline \multirow{4}{*}{$\begin{array}{l}\text { Psychology and counselling } \\
\text { (helping one's self-realiza- } \\
\text { tion) }\end{array}$} & \multirow{2}{*}{ Yes } & $\mathrm{N}$ & 8 & 3 & 9 & 20 & \multirow{6}{*}{$\begin{array}{l}\text { Chi-square: } 0.907 \\
\text { df: } 2 \\
\text { p: } 0.635\end{array}$} \\
\hline & & $\%$ & 22.2 & 12.5 & 19.1 & 18.7 & \\
\hline & \multirow{2}{*}{ No } & $\mathrm{N}$ & 28 & 21 & 38 & 87 & \\
\hline & & $\%$ & 77.8 & 87.5 & 80.9 & 81.3 & \\
\hline \multirow{2}{*}{ Total } & & $N$ & 36 & 24 & 47 & 107 & \\
\hline & & $\%$ & 100 & 100 & 100 & 100 & \\
\hline
\end{tabular}

Chi-square results show that considering experience of the participants' responses did not differ for this question (Chi-square: $5.773 ; 2.501 ; 0.911 ; 3.366 ; 0.907$, df: $2, \mathrm{p}>0.05$ ).

Question 5

The last question asked physicists is if "Developments in physics provide new paradigms for educational sciences." Respondents answered the question on a 4-point Likert-type scale. Distributions of responses are as follows.

Table 16. Frequency distribution of responses.

\begin{tabular}{lll}
\hline & N & $\%$ \\
\hline Definitely No & 4 & 3.7 \\
No & 32 & 29.9 \\
Yes & 45 & 42.1 \\
Definitely Yes & 26 & 24.3 \\
Total & 107 & 100 \\
\hline
\end{tabular}

According to the frequency distribution, 3.7\% of respondents definitely disagreed, $29.9 \%$ of respondents did not agree; $42.1 \%$ of participants agreed, and $24.3 \%$ of participants definitely agreed with this statement. In total $66.4 \%$ of participants have expressed their positive opinion; 
$32.6 \%$ of participants indicated a negative opinion about this question. Chi-square analysis results for theory and experiment group differentials are as follows.

Table 17. Chi-square results according to divisional differences.

\begin{tabular}{|c|c|c|c|c|c|c|}
\hline & & & Experimentalists & Theorists & Total & \\
\hline \multirow{6}{*}{$\begin{array}{l}\text { Developments in physics } \\
\text { provide new paradigms } \\
\text { to educational sciences. }\end{array}$} & \multirow{2}{*}{ Definitely No - No } & $\mathrm{N}$ & 24 & 12 & 36 & \multirow{7}{*}{$\begin{array}{l}\text { Chi-square: } 0.781 \\
\text { df: } 2 \\
\text { p: } 0.677\end{array}$} \\
\hline & & $\%$ & 35.8 & 32.4 & 34.6 & \\
\hline & \multirow[b]{2}{*}{ Yes } & $\mathrm{N}$ & 25 & 17 & 42 & \\
\hline & & $\%$ & 37.3 & 45.9 & 40.4 & \\
\hline & \multirow{2}{*}{ Definitely Yes } & $\mathrm{N}$ & 18 & 8 & 26 & \\
\hline & & $\%$ & 26.9 & 21.6 & 25.0 & \\
\hline Total & & $\mathrm{N}$ & 67 & 37 & 104 & \\
\hline
\end{tabular}

Chi-square test results show that there is no significant difference for this question between the responses obtained from the working groups (Chi-square: $0.781, \mathrm{df}: 2, \mathrm{p}>0.05$ ). Chisquare analysis results for participants' experience levels are as follows.

Table 18. Chi-square results according to participants' experience.

\begin{tabular}{|c|c|c|c|c|c|c|c|}
\hline & & & $\begin{array}{c}1-5 \\
\text { years }\end{array}$ & $\begin{array}{l}6-10 \\
\text { years }\end{array}$ & $\begin{array}{l}11 \text { and } \\
\text { over }\end{array}$ & Total & \\
\hline \multirow{6}{*}{$\begin{array}{l}\text { Developments in physics } \\
\text { provide new paradigms to } \\
\text { educational sciences. }\end{array}$} & Definitely No & $\mathrm{N}$ & 12 & 10 & 14 & 36 & \multirow{8}{*}{$\begin{array}{l}\text { Chi-square: } 4.277 \\
\text { df: } 4 \\
\text { p: } 0.370\end{array}$} \\
\hline & - No & $\%$ & 33.3 & 41.7 & 30.4 & 34.0 & \\
\hline & & $\mathrm{N}$ & 17 & 11 & 17 & 45 & \\
\hline & Yes & $\%$ & 47.2 & 45.8 & 37.0 & 42.5 & \\
\hline & & $\mathrm{N}$ & 7 & 3 & 15 & 25 & \\
\hline & Definitely Yes & $\%$ & 19.4 & 12.5 & 32.6 & 23.6 & \\
\hline \multirow{2}{*}{\multicolumn{2}{|c|}{ Total }} & $\mathrm{N}$ & 36 & 24 & 46 & 106 & \\
\hline & & $\%$ & 100 & 100 & 100 & 100 & \\
\hline
\end{tabular}

Finally, considering the experience of the participants' responses did not differ for this question (Chi-square: 4.277 , df: $4, \mathrm{p}>0.05$ ).

\section{Discussion}

The purpose of the study was to examine the perceptions and experiences of physicists working at CERN regarding the possible impacts of the developments in physics on educational sciences. The results of the research show that the developments in physics, particularly in quantum theory, have some impacts on education. First, as can be seen in Table 4, the majority of the participants $(88.8 \%)$ think that new developments in physics force us to change our view of physical reality. This finding reflects the conclusions of the pioneers of quantum theory. For instance, as Bohr (cited by Peat, 1990) puts it, there is no quantum world. There is only an abstract quantum mechanical description. Heisenberg (1958) indicates that atoms or the elementary particles are not real; they form a world of potentialities and possibilities rather than one of the objects or facts. Connected with this finding the majority of the participants $(88.9 \%)$ also think that developments after quantum theory reveal the need for new ways of thinking (Table 7). As Rusbult (2005) indicates, in order to understand this kind of reality, we must recognize that quantum common sense is not everyday common sense. As stated by Bohr, "Anyone who is not shocked by quantum theory has not fully understood it." 
PROBLEMS

OF EDUCATION

IN THE $21^{\text {st }}$ CENTURY

Volume 58,2014

64

Second, as can be seen in Table 10, some of the participants (34.9\%) declared that there is a need for a completely different language than that we are used to, and $65.1 \%$ of participants pointed out that existing languages should be enhanced with new words, symbols, or diagrams. This result is significant for the first hypothesis of the research. The participants' years of experience (Table 12) and departmental comparisons (Table 11) did not vary for this response, which means the differences among respondents are not significant here. Consequently, this ratio shows us that the developments in physics reveal the need for an enhanced language rather than the necessity of a completely new language. Garber (1999) underlines that there were no linguistic barriers between even mathematicians and physicists till at the beginning of the 1900 's. Developments in physics led physicists to the necessity of a new language. Difficulties in understanding the abstract world have forced physicists to join new games for new objects. However, due to the fact that vocabulary is not infinite the new objects had to be described by old words, and a way has not been found. Beside this, there is an analysis had been made by Bohm (1980), namely Rheomode, about the role of language in science and in thought. He says "When physicists discuss the subatomic world they inevitably use the words of everyday language. No matter how careful physicists may be they are constantly importing everyday concepts that have been refined by two hundred years of association with classical physics, into their discourse." With these reasons he tried to create a verb-based language to improve an alternative language dealing with the abstract world of quantum mechanics. More recently, a new language based on an intuitive graphical language, rather than on everyday language, has been developed in Coecke (2010) and Coecke and Kissinger (2014).

Third, in order to reveal physicists' opinions about which field(s) in educational sciences might have been influenced by recent developments in physics, the fourth question asked physicists "Which of the following fields in educational science might have been influenced by developments in physics?" $80.6 \%$ of participants stated that the field curriculum has been influenced first by the recent developments in physics. 53.7\% of participants remarked that the field measurement and evaluation has also been influenced by the recent developments in physics (Table 13). In other words, participants underlined the importance of two strongly connected issues: "What we teach" and "What is learned." This result directly supports criticism of the participants in the qualitative part of this research, and also supports Hurd's (1991), Vella's (2002), Rush et al (2004), Brookes's (2006), and Pospiech's (2008) remarks for curriculum issue in science.

The participants' years of experience (Table 15) did not vary for this expression, but compared with theoretical physicists (Table 14), experimentalists have strongly decelerated that the field curriculum has been influenced by recent developments in physics. Consequently, chi-square results revealed the significant differences (Chi-square: 5.050, $\mathrm{p}<0.05$ ) between the experimentalists and theoretical physicists for this question.

Finally, as can be seen in Table 16, compared with negative opinions (32.6\%) most of the participants $(66.4 \%)$ believe that developments in physics provide new paradigms to educational sciences. This result supports the second hypothesis of the research, but requires further investigation.

\section{Conclusions}

Since ideas go beyond disciplines more interactions become unavoidable to deal with dynamic nature of science. Considering obtained results, the lack of interdisciplinary interactions between education and physics, even between education, physics, and linguistics is obvious here. Accordingly, an interdisciplinary investigation is needed to understand deeply why the physics curriculum criticized for its deficiency. Another finding about language inadequacy requires an interdisciplinary research to reveal physicists' views too. Educators, philosophers, and linguistics are expected to make contribution to this issue. Finally, a comprehensive research could be undertaken to find out whether physicists have any recommendations for new words or concepts to contribute to the literature with their meaning. 


\section{References}

Bell, J. S. (1987). Speakable and unspeakable in quantum mechanics. UK: Cambridge University Press. Bell, J. S. (1996). On the problem of hidden variables in quantum mechanics. Reviews of Modern Physics, $38(3), 447-452$

Bell, J. S. (1997). Indeterminism and nonlocality. Quantum Philosophy Theories. Retrieved October 9th, 2011 from http://www.quantumphil.org/Bell-indeterminism-and-nonlocality.pdf.

Bohm, D. (1980). Wholeness and the implicate order. London: Routledge.

Bohm, D. (1989). Quantum theory. New York: Prentice-Hall.

Bohr, N. (1937). Causality and complementarity. Philosophy of Science, 4 (3), 289-298.

Bohr, N. (1961). Atomic theory and the description of nature. UK: Cambridge University Press.

Bokulich, A., \& Jeager, G. (2010). Philosophy of quantum information and entanglement. UK: Cambridge University Press.

Brookes, D. T. (2006). The role of language in learning physics. Unpublished dissertation. The State University of New Jersey.

Bub, J. (2012). Quantum entanglement and information. Retrieved November 20th, 2012 from http:// plato.stanford.edu/entries/qt-entangle/.

Coecke, B. (2010) Quantum picturalism. Contemporary Physics, 51 (1), $59-83$.

Coecke, B., \& Kissinger, A. (2014) Picturing quantum processes. UK: Cambridge Univesity Press (Forthcoming).

Creswell, J. W. (2005). Educational research: Planning, conducting, and evaluating quantitative and qualitative research. (2nd Ed.). New Jersey: Pearson Prentice Hall.

Desilet, G. (1999). Physics and language-science and rhetoric: Reviewing the parallel evolution of theory on motion and meaning in the aftermath of the Sokal Hoax. Quarterly Journal of Speech, 85, 339-360.

Deutsch, D. (1997). The fabric of reality. London: Penguin.

Dundar, S. (2013). Re-evaluating some of the fundamental educational questions in line with the development in new physics. Journal of Research in Educational Sciences, 1 (6), 12-48.

Einstein, A., Podolsky, B., \& Rosen, N. (1935). Can quantum-mechanical description of physical reality be considered complete? Physical Review, 47, 777-780.

Garber, E. (1999). The language of physics: The calculus and the development of theoretical physics in Europe-1750-1914. New York: Springer Science+Business Media.

Gottlieb, M. A., \& Pfeiffer, R. (2013). The Feynman lectures on physics Volume I. Retrieved September 18th, 2013 from http://www.feynmanlectures.caltech.edu/I toc.html.

Hameroff, S. Quantum consciousness. Retrieved November 22nd, 20013 from http://www.quantumconsciousness.org/publications.html.

Healey, R. (1989). The philosophy of quantum mechanics: An interactive interpretation. UK: Cambridge University Press.

Heisenberg, W. (1958). Physics and philosophy: The revolution in modern science (Introduction by F.S.C. Northrop). New York: Harper\&Row.

Hurd, P. D. (1991). Why we must transform science education? Educational Leadership, 49 (2), 33-35.

Jaeger, G. (2009). Entanglement, information, and the interpretation of quantum mechanics. Berlin/ Heidelberg: Springer

Jammer, M. (1989). The conceptual development of quantum mechanics. New York: American Institute of Physics.

Kuhn, T. S. (1962). The structure of scientific revolutions. USA: University of Chicago Press.

Lindley, D. (2007). Uncertainty: Einstein, Heisenberg, Bohr, and the struggle for the soul of science. New York: Knopf Doubleday.

Maudlin, T. (1995). Why Bohm's theory solves the measurement problem? Philosophy of Science, 62, 479-483.

Mittelstaedt, P., Prieur, A., \& Schieder, R. (1987). Unsharp particle-wave duality in a photon split-beam experiment. Foundations of Physics, 17 (9), 891-903.

Pagels, H. R. (2003). The cosmic code: Quantum physics as the language of nature (Kozmik kod: Kuantum fiziği maddeye yolculuk). Istanbul: Doruk Publishing.

Parker, B. (2006). Quantum legacy-the discovery that changed our universe (Kuantumu anlamak). Istanbul: Guncel Publishing.

Patton, M. Q. (1990). Qualitative evaluation and research method. CA: Sage. 
Selma Dundar-Coecke. Ramifications of Quantum Physics for Education

PROBLEMS

OF EDUCATION

IN THE $21^{\text {st }}$ CENTURY

Volume 58,2014

66 Peat, D. F. (1990). Einstein's moon: Bell's theorem and the curious quest for quantum reality. Chicago: Contemporary Books.

Penrose, R. (1989). The Emperor's New Mind: Concerning computers, minds, and the laws of physics. UK: Oxford University Press.

Pospiech, G. (2008). Teaching quantum theory-between thephotoelectric effect and quantum information. Retrieved May 13th, 2011 from http://sg.ucy.ac.cy/girep2008/papers/Teaching\%20quantum $\% 20$ theory $\% 20$ - $\% 20$ between $\% 20$ the $\% 20$ photoelectric $\% 20$ effect $\% 20$ and $\% 20$ quantum $\% 20$ information.pdf.

Rusbult, C. (2005). Quantum mechanics: Basic scientific principles, philosophy and interpretations, speculations about new age religion. Retrieved September 4th, 2013 from http:/www.asa3.org/ASA/ education/views/quantum-z.htm\#religion.

Rush, K. L., Peel, K., \& McCracken, B. (2004). Empowered learning on the inside: An externship experience. Nursing Education Perspectives, 25 (6), 284-291.

Schreiber, Z. (1994). The nine lives of Schrodinger's cat on the interpretation of non-relativistic quantum mechanics. Unpublished master thesis. Imperial College of Science.

Smith, J. A., \& Eatough, V. (2006). Interpretative phenomenological analysis. In M. Breakwell, S. Hammond, C. Five-Schaw \& J. A. Smith (Eds.), Research Methods In Psychology (322-341). London: Sage.

Strauss, A. L. (1987). Qualitative analysis for social scientists. UK: Cambridge University Press.

Teddlie, C., \& Tashakkori, A. (2009). Foundations of mixed methods research: Integrating quantitative and qualitative approaches in the social and behavioral sciences. CA: Sage.

Vella, J. (2002). Quantum learning: Teaching as dialogue. New Directions for Adult and Continuing Education, 93, 73-84.

Vygotsky, L. S. (1986). Thoughts and language. Cambridge, MA: MIT Press.

Advised by Paolo Bussotti, Commission for the Publication of the National Edition of Federigo Enriques's Works, Italy

Received: February 05, 2014

Accepted: March 10, 2014

Selma Dundar-Coecke

Post-Doc, Academic Visitor, Department of Computer Science, University of Oxford, Oxford, UK.

E-mail: selma.dundar@cs.ox.ac.uk

Website: http://www.ox.ac.uk 